\title{
Term-creation strategies used by Ndebele translators in Zimbabwe in the health sector: A corpus-based approach
}

\author{
Ketiwe Ndhlovu \\ Department of Linguistics, University of South Africa, Pretoria \\ Email:ndhlok@unisa.ac.za
}

\begin{abstract}
In the scientific arena, many African languages face the challenge of a lack of terminology. That is, translators who translate from developed Western languages into African languages often encounter a lack of adequate terminology in their efforts to communicate between these languages. The health sector seems particularly problematic, since it involves a continuously evolving discipline that requires continuously evolving terminology creation. This article explores strategies used by Ndebele translators to create terms in the health sector. In order to identify specialised terms and their Ndebele translations, the English-Ndebele Parallel Corpus (ENPC), created by Ndhlovu (2012), was interrogated. Borrowing in the form of pure loaning acronyms and abbreviations, pure loaning words, indigenisation, pure loan words preceded by an explanation, and abbreviations preceded by an explanation were identified as the most commonly used strategies in Ndebele medical translations, followed by semantic shift using borrowed synonyms and paraphrasing. The least used strategies were paraphrased acronyms and abbreviations, coinage and compounding. In the article, it was noted that in order to fully understand the strategies employed by Ndebele translators from a corpus-based approach using ParaConc, there is a need to have knowledge of prefixal elements of Ndebele terms. This is because searching for the head word outside its prefixal elements brings about incomplete results, thereby presenting an incomplete picture of the strategies under study.
\end{abstract}

Keywords: term creation, terminology, strategies, specialised terms, corpus, parallel corpus, corpus analysis tools

\section{Introduction}

It is a well-known fact that many African languages encounter problems of term scarcity, especially in technical and scientific arenas. This subject is well documented by scholars such as Trew (1994), Mtintsilana and Morris (1988), Hadebe (2000, 2006), Kruger and Wallmach (1999), Van Huyssteen (1999), Gauton, Taljard and De Schryver (2003), Moropa (2005), Kruger (2010) and Ndhlovu (2012), among others, who write from different perspectives and who illustrate how speakers of different African languages struggle to express themselves in specialised fields. Gauton, Taljard and De Schryver (2003:81) explain that the single biggest problem that translators who translate into African languages have to contend with is a lack of 
terminology in the majority of specialist subject fields. This lack of terminology in African languages seems to be the result of many factors. Van Huyssteen (1999) identifies nine characteristics related to term creation in Africa, namely the time factor, Eurocentrism, standardisation, foreign sounds, multilingualism, trendy words, purity, the abundance of synonyms, and the lack of coordination of efforts. In addition to these factors is the issue of exposure that applies to term creation in specialised fields. That is, many African languages have had little exposure in the scientific and technical arenas, and this seems to have compounded the terminology development gap/problem. Trew (1994:77-78) elaborates that:

[t]he history of South Africa has been such that indigenous South African languages have been little used in technical fields, in national politics or in economic management. [...] If a source text is not from a domain in which the use of African languages is currently well established, then an accessible translation will require considerable resources of adaptation and explanation, and no bilingual dictionary will provide much help.

Trew's comment about South Africa, though made more than a decade ago, is still true today of many African languages which are not only struggling in terms of terminology, but also as regards resource availability. In other words, many African languages do not have specialised dictionaries to support translators during the process of translating, thereby compounding the situation at hand. This problem can be illustrated using the Zimbabwean Ndebele language which to date has only three dictionaries, namely a general monolingual dictionary IsiChazamazwi SesiNdebele (Hadebe 2001), a specialised Ndebele dictionary of music terms IsiChazamazwi sezoMculo (Nkomo and Moyo 2006), and Pelling's (1971) English-Ndebele bilingual dictionary. Having access to only three dictionaries means that translators have limited resources to support them in their trade, and general dictionaries are of little use in medical translations.

Other factors that widen the gap between African and European languages include globalisation and technology. The ever-increasing speed of technological changes leads to an increase in the need for terminology development in languages other than English (English being the language used most often in technology). Valeontis and Mantzari (2006:3) state that in all areas of science and technology there is a need for new terms in order to name new objects, new parts of objects or new procedures. This means that the subject of terminology development is and will continue to be important in Africa for the foreseeable future, as will be the need for innovative and integrated approaches to alleviate this problem. The fact that African languages develop at different rates means that the problem of terminology development is experienced differently by each language, once again pointing to the need for individual approaches to terminology development in the respective African languages. Through these endeavours, a practical solution may be found.

In light of the information presented above, this article explores how English-Ndebele translators deal with the challenge of term scarcity when translating specialised terms in the health sector. The focus of this study is on term-creation strategies used by Ndebele translators, and this article compares and contrasts technical/scientific terms from English as the source language to Ndebele as the target language. An English-Ndebele Parallel Corpus (ENPC), created by Ndhlovu (2012) for her PhD studies, was interrogated using ParaConc, a 
multilingual concordance tool. The ENPC is an invaluable aid for understanding termcreation processes in Ndebele translations in Zimbabwe's health sector.

\section{Terminology development}

The subject of terminology development is interdisciplinary in nature. Valeontis and Mantzari (2006:1) state that linguistic aspects of term creation are of major interest not only to terminologists, terminographers and subject field specialists, but also to translators, interpreters and technical writers, especially when translators happen to work with less widely-used languages such as Greek, where the lack of adequately developed reference tools such as specialised dictionaries and glossaries very often compels them to become neologists or creators of new words or senses. Since the topic of terminology development is interdisciplinary, this study approaches this problem from the point of view of translation studies, focusing on translators who translate from developed Western languages into developing African languages.

In the field of translation studies in Africa, translators are compelled to come up with new terms to express new and, at times, foreign concepts, yet many do not have the skills to develop terminology in this manner. According to Cluver (1989:254), translators become neologists when the translators who are working on a developing language actively participate in the elaboration or development of terminology. They need a deeper understanding of wordformation processes than their counterparts who work on so-called "developed" languages. In other words, it seems that translators who translate into African languages constantly find themselves caught between the process of translating and that of term creation. As these translators are expected to perform miracles in order to ensure the smooth transfer of vital information from one language to the other, it is imperative that various studies examine and report on the different strategies that are used to translate technical/scientific texts into languages of limited diffusion (LLDs) or minority languages (Kruger 2010). With English as the official and dominating language, Ndebele is but one of Zimbabwe's many minority languages. Examining translators' strategies in this manner should shed light on how African languages are developing as scientific/technical languages, and expose the processes involved in creating terms - this may be beneficial to other minority languages as well as to lexicographers. Lastly, such studies could help develop awareness of the importance of terminology and resource development in the African languages.

The section that follows will provide a definition of "terminology" before discussing different term-creation strategies in more detail.

\subsection{Terminology}

According to Valeontis and Mantzari (2006:2), "terminology" has three meanings:

The scientific field pertaining to the study of relations between concepts and their designations (terms, names and symbols) and the formulation of principles and methods governing these relations in any given subject field; the task of collecting, processing, managing and presenting terminological data in one or more languages, as well as the set of terms belonging to the special language of a specific subject field. 
Terminology in this article will be concerned with the study of concepts and their designations (the terms and their translations) in the health sector. "Health" can be used as a general term that covers various aspects of medicine and its specialised language that identifies and describes diseases, their modes of transmission and treatment.

\section{Methodology}

As stated previously, the ENPC (Ndhlovu 2012) was analysed using a multilingual concordance - ParaConc. The ENPC, which comprises 84957 words (with 48120 words in the English file and 36837 words in the Ndebele file), was firstly aligned at word, phrase, sentence and paragraph level to make it easier to identify English source terms and their Ndebele translations. From the beginning, it is important to note that the ENPC is a specialised corpus which was created using public texts from the health sector. This means that the corpus has a higher frequency of specialised terms. Furthermore, the texts used to create the corpus were translated by 14 different translators, meaning there are variations in the terms used by translators. For example, a term like "condom" is translated differently by different translators as icondom, ikhondomu and umncwado, and all these are different strategies used by Ndebele translators.

After aligning the English and Ndebele files, the process of term extraction followed. Terms were extracted using ParaConc's "search" feature. To search for terms, a term is entered into the search box under a particular language, in this case either English or Ndebele. A processing bar then appears and the results of the search follow. Figure 1 illustrates the results of the search term "HIV".

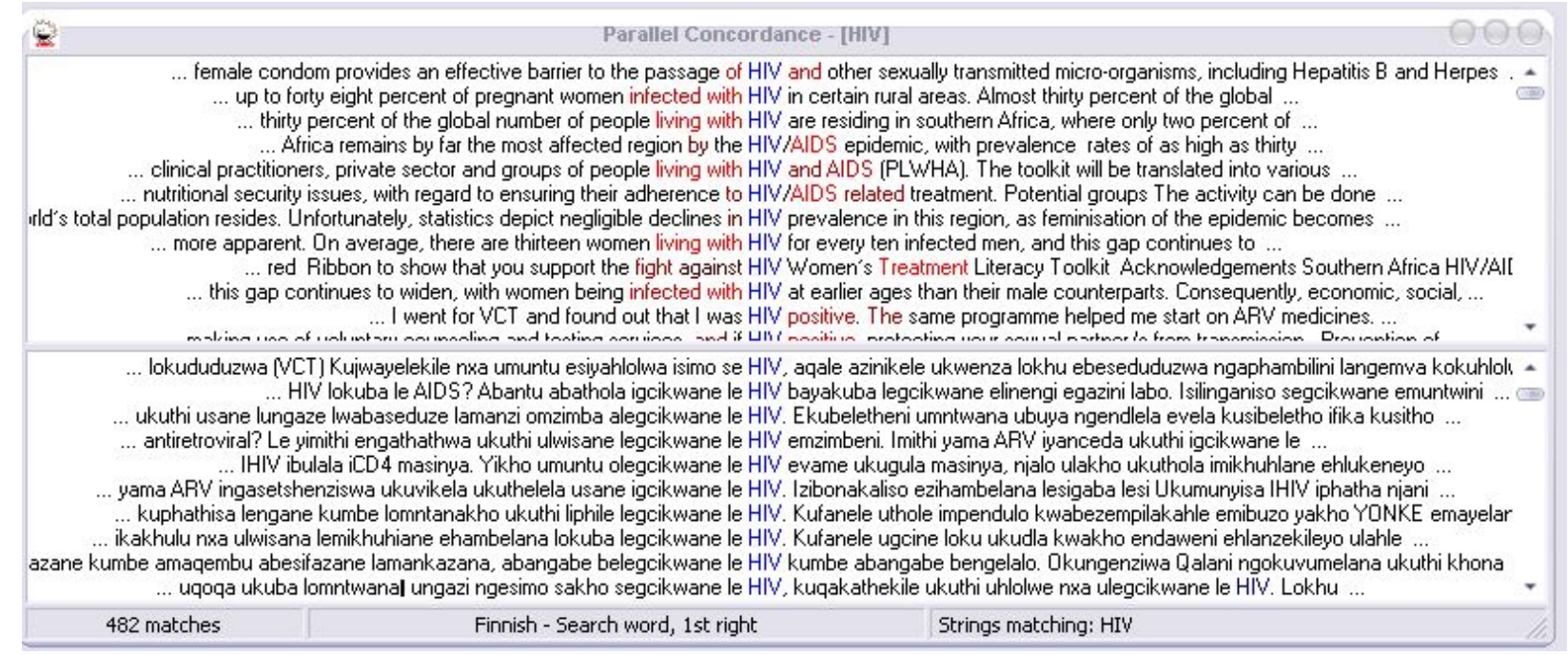

Figure 1. Results of the search for the term "HIV"

Figure 1 illustrates the search word "HIV" in the upper window, and the most commonly used translation for the term in Ndebele in the lower window. The highlighted words surrounding the head word indicate potential collocates of the search word. In the example above, the English term "HIV" is translated as $H I V$ in Ndebele, meaning the source term is retained in its original form in the target language. In order to get a fuller picture of how frequently a particular term or phrase appears in the Ndebele file, it was also necessary to search for terms 
based on their prefixal elements. For example, whilst the term "HIV" appears 399 times as $H I V$, it appears 48 times as $i H I V$, six times as leHIV and twice as kweHIV. A simple search of terms outside their prefixal elements therefore presents an incomplete picture of the distribution of the terms and, in turn, an incomplete picture of the strategies used by Ndebele translators in the health sector.

Additionally, at the bottom of the lower window, the word count of the term "HIV" indicates that it has 482 hits in the English file and 399 hits in the Ndebele file. Word counts are important in this article as they show how frequently a term is used by the Ndebele translators, thereby proving whether a strategy is popular among the translators or not. The results from different words were tallied together to obtain the overall word count of a strategy. In order to gather frequencies of target terms, the frequency feature was used. The following section presents the strategies used by Ndebele translators in Zimbabwe.

\section{Term-creation strategies used by Ndebele translators}

Ndebele translators use different strategies to translate specialised terms in the health sector. These include pure loaning of words, acronyms and abbreviations; paraphrasing abbreviations and acronyms; pure loaning preceded by an explanation; abbreviation preceded by an explanation; indigenisation; paraphrasing; using borrowed synonyms; semantic shift; compounding and coinage. These strategies are presented in the subsequent sections, however, the concept of 'borrowing' is first presented.

\subsection{Term creation through borrowing}

Borrowing is one of the strategies that is used by Ndebele translators to translate specialised terms in the health sector. Borrowing or loaning involves taking words from the source language and applying them in the target language. In the ENPC, the following types of borrowing are observable:

- Indigenised loan words

- Pure loan words

- Acronyms and abbreviations

- Acronyms or abbreviation preceded by an explanation

- Pure loan word preceded by an explanation

\subsubsection{Indigenised loan words}

Indigenisation of terms involves changing the structure, spelling and pronunciation of these terms to suit the target language; the meaning and sound, however, remain the same (Ndhlovu 2012:183). This type of borrowing is common in the ENPC as shown by the examples in Table 1. 
Table 1. Indigenised borrowings

\begin{tabular}{|l|c|c|c|}
\hline \multicolumn{1}{|c|}{ Source term } & Target term & ENG word count & ND word count \\
\hline 1. condom & ikhondomu & 119 & 38 \\
\hline 2. pills & amaphilisi & 11 & 38 \\
\hline 3. gloves & amagilavu & 20 & 8 \\
\hline 4. plastic & ipulastiiki & 16 & 1 \\
\hline 5. rubber & irabha & 4 & 1 \\
\hline 6. doctor & udokotela & 74 & 49 \\
\hline \multicolumn{2}{|c|}{ Overall word count: 146} & & Frequency: 0.3963 \\
\hline
\end{tabular}

Table 1 presents selected English terms ("Source term"), Ndebele borrowings in the ENPC ("Target term"), the number of times the source term appears in the source text ("ENG word count"), and the number of times the translated term appears in the target text ("ND word count"). Lastly, the overall word count of all indigenised terms in the parallel corpus, and the frequency of these terms in the Ndebele file are both indicated in the final row.

Indigenisation as a strategy has an overall word count of 146 and a frequency of 0.3963 . In comparison with other strategies which will be discussed later, indigenisation is not the strategy most used by translators to create terms in the ENPC. Another important finding that is observable in Table 1 is that it is vital to understand the prefixal elements of all search words in order to get a full picture of the strategies used by Ndebele translators, and this possibly applies to all languages that are written conjunctively. That is, a stem in Ndebele can have multiple concords, and these appear as separate words with separate frequencies. For example, the stem -khondomu (example 1), which has a $0 \%$ frequency in the ENPC and is not recognised as a word outside its prefixal elements, has the prefixes $i$ - and le-. A search of these terms reveals that the term ikhondomu appears 38 times and lekhondomu only once in the Ndebele file. This means that a complete picture of how a word is translated into Ndebele requires intimate knowledge of prefixal elements of Ndebele terms. This concept applies to many Ndebele words which have different prefixal elements depending on the context in which they are used. Another example is the term "doctor" (example 6) which is translated 48 times as udokotela, 17 times as lodokotela, and 8 times as kudokotela.

Additionally, in example 2, there is a disparity between the English word count and Ndebele word count, with the Ndebele term amaphilisi having more entries. This is a result of the lack of terms to express different English words in the Ndebele language. Consequently, the English words "tablets", "dose", "pain killers" and "medicines" are all translated using the term amaphilisi. The strategy of indigenising loan words is advantageous in that the words adopt the orthographic structure of the target language, making them easier for pronunciation by Ndebele speakers. The findings of this study complement those of Gauton, Taljard and De Schryver (2003:83) who explored the strategies used to create terms in 10 South African languages. They state that African languages form terms through transliteration, a process of adapting the phonological structure of the loan word to the sound system of the borrowing language (herein referred to as indigenisation). However, the rate at which this happens differs from language to language, with Zulu depending more on non-nativised loan words, 
and Swati relying on both non-nativised and nativised loan words, whereas Ndebele, Xhosa, Tswana, Sepedi, Sesotho, Venda, Tsonga and Afrikaans rely more on transliteration than pure loan words (Gauton, Taljard and De Schryver 2003:83). Similar to Zulu, it seems as if (Zimbabwean) Ndebele relies more on pure loan words than indigenised loan words, as shall be shown in the subsequent section.

\subsubsection{Pure loan words}

Pure loans words are defined as source words which are retained in the target text. Usually, these words change neither in form nor in meaning, however, as shall be shown below, the words gain prefixal elements so as to fit in with the Ndebele style of writing. Put differently, the words retain their original structure except for the prefixes. For example, the term "condom" which is retained in its pure form, takes the form of a stem with various prefixes, such as $i$-condom and le-condom as shown in Table 2 below. What follows are more examples of terms that have been retained in their pure form in the Ndebele language.

Table 2. Pure loan words

\begin{tabular}{|l|l|c|c|}
\hline Source term & \multicolumn{1}{|c|}{ Target term } & ENG word count & ND word count \\
\hline 1. condom & $\begin{array}{l}\text { icondom } \\
\text { lecondom }\end{array}$ & 119 & 49 \\
\hline $\begin{array}{c}\text { 2. Helper T } \\
\text { lymphocytes }\end{array}$ & Helper T lymphocytes & 1 & 1 \\
\hline 3. glands & ama gland & 2 & 2 \\
\hline 4. antibodies & ama antibodies & 5 & 2 \\
\hline 5. antiretroviral & ama antiretroviral & 48 & 38 \\
\hline 6. hormones & ama hormones & 4 & 1 \\
\hline $\begin{array}{c}\text { 7. vertical } \\
\text { transmission }\end{array}$ & vertical transmission & 3 & Frequency: 0.5320 \\
\hline \multicolumn{2}{|r|}{ Overall word count: 196} & & 3 \\
\hline
\end{tabular}

Compared to the strategy of indigenisation, which has a frequency of $0.3963 \%$, pure loaning, which has an overall word count of 196 and a frequency of 0.5320 , is more common in the ENPC. Although the overall word count and frequency of pure loan words seems low, the number of individual or distinct words identified as loan words is higher than all the other strategies. In the Ndebele file, 84 words were identified as pure loan words, some accompanied by prefixes and some not. Of these, 74 appear twice or less in the Ndebele file. From these findings, it seems the more difficult a term is, the higher the chances of it being retained in its pure form. Notably, in the ENPC most names of diseases, medicines and internal body parts are presented in their original form:

\section{Diseases: $\quad$ Kaposi's sarcoma, Herpes Simplex, Candidiasis, Hepatitis B \\ Medicines: Zidovudine, Codeine, Panadine, Betadine, antibiotics, Efavirenz, Nevirapine, Lamuvudine, Stavudine}

Treatment methods: Aroma treatment, yoga treatment, reflexology, acupuncture

Generally, pure loan words are not easily pronounced as their sound patterns are not in harmony with the traditional sound patterns of Ndebele, and usually, pronunciation and 
meaning go hand-in-hand. Pure borrowing is also evidenced in the translation of acronyms and abbreviations.

\subsubsection{Acronyms and abbreviations}

Valeontis and Mantzari (2006:6) define acronyms as words that are formed by combining the initial letters or syllables of all or several of the elements of a complex term or name. Acronyms are always pronounced syllabically just like regular words, e.g. "laser" from Light Application by Stimulated Emission of Radiation. The South African Concise Oxford Dictionary (2007) defines an abbreviation as a shortened form of a word or phrase. The difference between the two is that abbreviations are always pronounced as a sequence of letters, and they function as normal word forms taking plural suffixes as well (Moropa 2005:173), whilst acronyms take up the form of a word in the target language and are more likely to be assimilated into the language. Examples of how acronyms and abbreviations are translated in the ENPC are presented in Table 3.

Table 3. Abbreviations and acronyms

\begin{tabular}{|c|c|c|c|}
\hline Source term & Target term & ENG word count & ND word count \\
\hline \multicolumn{4}{|c|}{ Acronyms } \\
\hline 1. PEP & $\begin{array}{c}\text { lwe PEP } \\
\text { iPEP }\end{array}$ & 17 & $\begin{array}{c}12 \\
2 \\
\end{array}$ \\
\hline 2. AIDS & iAIDS & 135 & 135 \\
\hline 3. SAfAIDS & $\begin{array}{c}\text { iSAfAIDS } \\
\text { SAfAIDS }\end{array}$ & 8 & $\begin{array}{l}7 \\
3\end{array}$ \\
\hline \multicolumn{4}{|c|}{ Abbreviations } \\
\hline 4. ART & ye $A R T$ & 75 & 69 \\
\hline 5. ARV & ama $A R V$ & 183 & 183 \\
\hline 6. PLWHA & PLWHA & 18 & 4 \\
\hline 7. MIPA & $M I P A$ & 3 & 3 \\
\hline \multicolumn{2}{|c|}{ Overall word count: 849} & & Frequency: 2.3047 \\
\hline
\end{tabular}

With an overall word count of 849 and a frequency of 2.3047, pure loaning of acronyms and abbreviations is the most used strategy in the Ndebele language. These statistics confirm Baker's $(1992: 35,2011)$ assertion that acronyms and abbreviations are usually retained in their pure forms in the target language. In Table 3, there is a high correlation between the source-term word counts and the target-term word counts. Most abbreviations and acronyms are accompanied by prefixes and these influence the frequency outcomes. Nonetheless, the acronyms "AIDS" and "PEP" and the abbreviation "ARV" maintain their forms in the target text as shown in (i) and (ii) below:

(i) Source language (SL): Can AIDS be cured?

Target language (TL): Iyelapheka na iAIDS?

Back translation (BT): Is AIDS curable?

(ii) SL: I also took ARV medicines like you for PEP.

TL: Lami ngithatha imithi yama ARV ngaphansi kohlelo lwe PEP.

BT: I am also taking ARV medicines under the PEP programme. 
Acronyms are usually pronounced as words in Ndebele, whilst in abbreviations the letters are pronounced in sequence. A strategy of introducing abbreviations that is used by Ndebele translators is that of abbreviations preceded by an explanation, which is discussed in the following section.

\subsubsection{Abbreviations preceded by explanations}

Table 4 shows how Ndebele translators paraphrased abbreviations and then provided the original form in brackets.

Table 4. Abbreviations preceded by explanations

\begin{tabular}{|c|c|c|c|}
\hline Source term & Target term & $\begin{array}{l}\text { ENG word } \\
\text { count }\end{array}$ & $\begin{array}{l}\text { ND word } \\
\text { count }\end{array}$ \\
\hline $\begin{array}{l}\text { 1. Highly Active } \\
\text { Antiretroviral } \\
\text { Therapy (HAART) } \\
\end{array}$ & $\begin{array}{l}\text { Ukwelatshwa ngemithi yama } \\
\text { antiretroviral (Highly Active } \\
\text { Antiretroviral Therapy) (HAART) }\end{array}$ & 1 & 1 \\
\hline 2. MIPA & $\begin{array}{l}\text { Abaphila legcikwane le AIDS } \\
\text { (MIPA) }\end{array}$ & 3 & 1 \\
\hline $\begin{array}{l}\text { 3. MIWA } \\
\text { (Meaningful } \\
\text { involvement of } \\
\text { Women } \\
\text { Affected/Infected } \\
\text { by HIV/AIDS) }\end{array}$ & $\begin{array}{l}\text { Ukuphatheka okugcweleyo } \\
\text { Kwabesifazane abelegcikwane } \\
\text { leHIIV labalodubo olungabe } \\
\text { lubangelwa yi HIV/AIDS } \\
\text { okuthiwa yi Meaningful } \\
\text { Involvement of Women } \\
\text { Affected/Infected by HIV/AIDS } \\
\text { (MIWA) }\end{array}$ & 2 & 2 \\
\hline 4. VCT & Ukuhlolwa lokududuzwa (VCT) & 7 & 2 \\
\hline \multicolumn{2}{|c|}{ Overall word count: 20} & & $\begin{array}{l}\text { Frequency: } \\
0.0542\end{array}$ \\
\hline
\end{tabular}

This strategy is usually used when an abbreviation is being introduced, hence the low word count of 20 and a frequency of 0.0542 . After the acronyms or abbreviations are introduced, they are then retained in their pure form. The advantage of adding an explanation is that abbreviations are immediately clear to the readers, thus making the meaning clearer to target readers. A similar strategy to this is that of pure loan words preceded by an explanation. This strategy is discussed below.

\subsubsection{Pure loan words preceded by explanations}

This method of developing terms involves explaining a foreign concept and then putting the loan word in brackets. This strategy is functional in that it gives meanings for concepts in both the source and target languages, thereby clarifying the message. This strategy is useful for introducing new concepts into a language as it provides both the source term and its translation in the target language. Table 5 shows how this strategy is used. 
Table 5. Pure loan words preceded by explanations

\begin{tabular}{|c|c|c|c|}
\hline Source term & Target term & $\begin{array}{l}\text { ENG word } \\
\text { count }\end{array}$ & $\begin{array}{l}\text { ND word } \\
\text { count }\end{array}$ \\
\hline 1. disclosure & $\begin{array}{l}\text { ukuphuma } \\
\text { egcekeni(disclosure) }\end{array}$ & 13 & 6 \\
\hline $\begin{array}{l}\text { 2. informed } \\
\text { consent }\end{array}$ & $\begin{array}{l}\text { ukuvuma ukuyahlolwa usazi } \\
\text { imibiko egcweleyo (informed } \\
\text { consent) }\end{array}$ & 1 & 1 \\
\hline $\begin{array}{l}\text { 3. second line } \\
\text { treatment }\end{array}$ & $\begin{array}{l}\text { isigaba sesibili (second line } \\
\text { treatment) }\end{array}$ & 3 & 2 \\
\hline $\begin{array}{l}\text { 4. Pelvic } \\
\text { Inflammatory } \\
\text { Disease (PID) }\end{array}$ & $\begin{array}{l}\text { umkhuhlane ohlasela iqolo } \\
\text { (Pelvic Inflammatory Disease) } \\
\text { / ukuvuvuka kweqolo }\end{array}$ & 5 & 3 \\
\hline \multicolumn{2}{|c|}{ Overall word count: 48} & & $\begin{array}{c}\text { Frequency: } \\
0.1303\end{array}$ \\
\hline
\end{tabular}

This strategy has an overall word count of 48 and a frequency of 0.1303 , which is low compared to pure loaning of words, acronyms, abbreviations and indigenisation. The low word count may be explained in terms of Ndebele translators switching strategies from pure loan words preceded by an explanation to paraphrasing after the terms have been introduced. While it is commonly agreed in the field of Translation Studies that acronyms are usually translated directly into the target language, Ndebele translators show that there are exceptions to the rule. They do this by paraphrasing acronyms and abbreviations, as elaborated in the following section.

\subsubsection{Paraphrased acronyms and abbreviations}

Paraphrased acronyms and abbreviations explain the meaning of the abbreviated word in its original form. For example, the acronym "STI" stands for "Sexually Transmitted Infections", and the paraphrase explains what this means in Ndebele. Therefore, in instances where the source text presents the acronym "STI", most Ndebele translators will use the paraphrase imikhuhlane yengulamakhwa or simply ingulamakhwa. Table 6 presents paraphrased abbreviations, as they are more common than acronyms.

Table 6. Paraphrased abbreviations

\begin{tabular}{|c|l|c|c|}
\hline Source term & \multicolumn{1}{|c|}{ Target term } & ENG word count & ND word count \\
\hline 1. MTCT & $\begin{array}{l}\text { yikuthelelwa kosane igcikwane } \\
\text { ngunina }\end{array}$ & 2 & 2 \\
\hline 2. PTCT & $\begin{array}{l}\text { yikuthelelwa kosane igcikwane } \\
\text { ngabazali }\end{array}$ & 4 & 2 \\
\hline 3. PLWHA & abaphila legcikwane le HIV & 18 & 20 \\
\hline 4. ANC & ukuhlolwa uzithwele & 4 & 3 \\
\hline \multicolumn{2}{|c|}{ Overall word count: 31 } & & Frequency: 0.0841 \\
\hline
\end{tabular}

With an overall word count of 31 and a frequency of 0.0841 , the strategy of paraphrasing acronyms and abbreviations is used to a lesser extent than loaning acronyms and 
abbreviations. Furthermore, the paraphrased terms do not have frequencies, as the "hot words" feature generally picks up single words and not phrases or sentences. Interestingly, some of the paraphrased abbreviations have gained popularity in the Ndebele language, for example, "PTCT" is commonly translated as ukuthelelwa kosane igcikwane ngabazali and "ANC" as ukuhlolwa uzithwele. Still, these paraphrased translated terms have not been converted into acronyms as in the case of Afrikaans where an English abbreviation like "SAQA" has become the acronym SAKO (Suid-Afrikaanse Kwalifikasie-owerheid), or where the acronym "AIDS" is translated as vigs and spelled with lower case letters.

In the ENPC, some Ndebele translators take the middle line by using both the borrowed word (pure and/or indigenised) and the indigenous word in a sentence. They translate using synonyms of the source word as explained in the next section.

\subsubsection{Using borrowed synonyms}

Hadebe (2000:230) mentions that "in the Ndebele language some words are adopted and adapted into the morphology of the language and these adoptives end up not being discernible from the rest". Such words were found to co-exist with the indigenous words in the ENPC. Moropa (2005:179) further explains that "the loan word and the Xhosa word co-occur in the lexicon and are synonyms, in that they have the same meaning". The same is true of Ndebele as shown by the examples in Table 7 .

Table 7. Borrowed synonyms

\begin{tabular}{|l|c|c|c|}
\hline Source term & Target term & ENG word count & ND word count \\
\hline 1. AIDS & ingculaza/ingculazi & & 8 \\
& iAIDS & 135 & 125 \\
\hline 2. condom & icondom/ & \multirow{2}{*}{119} & 49 \\
& ikhondomu/ & & 38 \\
& umncwado & \multirow{2}{*}{30} & 31 \\
\hline 3. ring & iringi/ & 17 \\
\hline 4. gloves & indandatho & \multirow{2}{*}{20} & 10 \\
& amagloves/ & & Frequency: 0.7356 \\
\hline \multicolumn{2}{|c|}{ Oragilavu }
\end{tabular}

Table 7 shows that most translators prefer the borrowed acronym "AIDS" to the coinage ingculaza. However, when it comes to the term "condom", all three translations feature a great deal in the corpus, although icondom (pure loan word) is most used. Some Ndebele translators, however, use both words in a sentence:

(iii) ST: It is therefore wise to use condoms to stop the exchange of body fluids

TT: Ngokunjalo ukusebenzisa umcwado (condom) yibuhlakaniphi obukhulu ngoba kwenqabela ukunikana amanzana

BT: Therefore to use a male protective cover (condom) shows great wisdom because it prevents the transfer of liquids 
(iv) ST: Wear gloves or bags on hands TT: Qqoka amagloves/ amagilavu BT: Wear gloves

The examples above show that in Ndebele, English loan words (pure and indigenised) coexist with indigenous words which have been formulated by the language speakers to express new concepts in their languages. Some of these words, through constant use, have come to be accepted as indigenous words, for example, ingculaza, ibhanditshi and amakhondomu. This strategy contributes positively to the Ndebele language by developing its lexicon.

\subsubsection{Semantic shift}

Hadebe (2000:229) defines semantic shift as a process during which there is a shift in reference but not in sense, such that the coined term is used in the specialised field, although in ordinary speech the original and the new one co-exist. In other words, an everyday word gains new meaning by being used in specialised environments. Satyo (in Moropa 2004:127) concurs with this assertion by saying, "the new meaning springs from the original meaning and the relationship between these two does not fade". This new meaning is specialised in form, hence, Hadebe (2000:229) adds that

in semantic specialisation a word acquires a specialized technical sense different from the one it previously held in ordinary speech, whereas in generalization the semantic field of the word expands to refer to senses previously not covered by the particular term in ordinary speech. This area has potential for Ndebele and other African languages.

Hadebe's statement here is valid as the method of extending the meanings of words contributes greatly to term development. The following examples in Table 8 highlight this strategy:

Table 8. Semantic shift

\begin{tabular}{|l|c|c|c|}
\hline \multicolumn{1}{|c|}{ Source term } & Target term & ENG word count & ND word count \\
\hline 1. testing/ test & ukuhlolwa & 27 & 13 \\
\hline 2. virus & $\begin{array}{c}\text { Igcikwane } \\
\text { igciwane }\end{array}$ & 50 & 122 \\
& $\begin{array}{c}\text { Isimo } \\
\text { ngesimo }\end{array}$ & 55 & 36 \\
\hline 3. status & lobandlululo & 17 & 24 \\
\hline 4. discrimination & $\begin{array}{c}\text { ukuthelelwa/ } \\
\text { ukuthelelana/ } \\
\text { ukumemetheka }\end{array}$ & 34 & 15 \\
\hline 5. transmission & & 6 \\
\multicolumn{2}{|c|}{ Overall word count: 422 } & Frequency: 1.1455 \\
\hline
\end{tabular}

Semantic shift as a strategy has a high word count of 422 and a frequency of 1.1455 in the Ndebele file. It is the second most used strategy to pure loaning of acronyms and abbreviations. In Table 8, the frequencies of the Ndebele terms seem lower because of the presence of prefixal elements. For example, the term "status", which appears 55 times, is 
translated as isimo, which appears 36 times. The word count is lower as the term has a number of concords, for example ngesimo appears 24 times. With regard to the term "virus", which appears 50 times in the English corpus, there are more entries in the Ndebele corpus as represented by the Ndebele translations igcikwane (122) and igciwane (19). This is because, in some instances, "HIV" is simply referred to as igcikwane as shown in Figure 2 below:

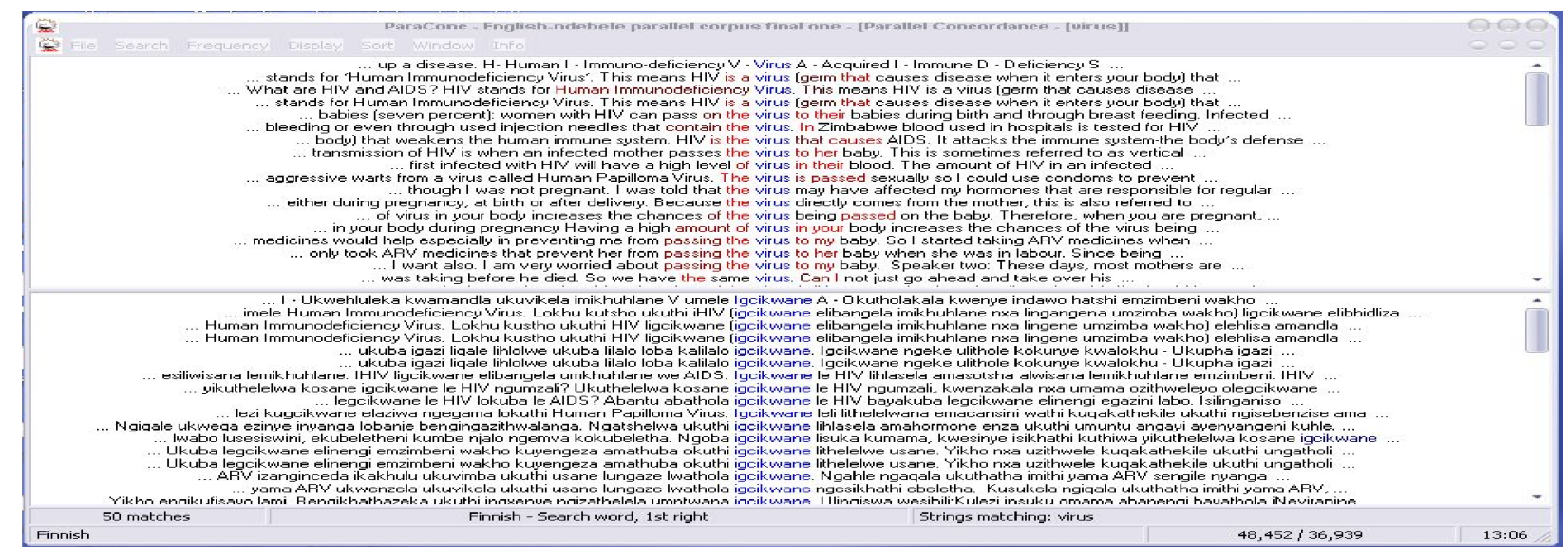

Figure 2. Translation of the term "virus"

Through the semantic-shift strategy, Ndebele as a language is gaining new meanings and new words through use in specialised environments such as the health sector, thus leading to its development. Some of the words are so common in the language that all Ndebele translators are in agreement in terms of their use. Another example is the translation of the term "transmission" as ukuthelelwa (see Figure 3 below).

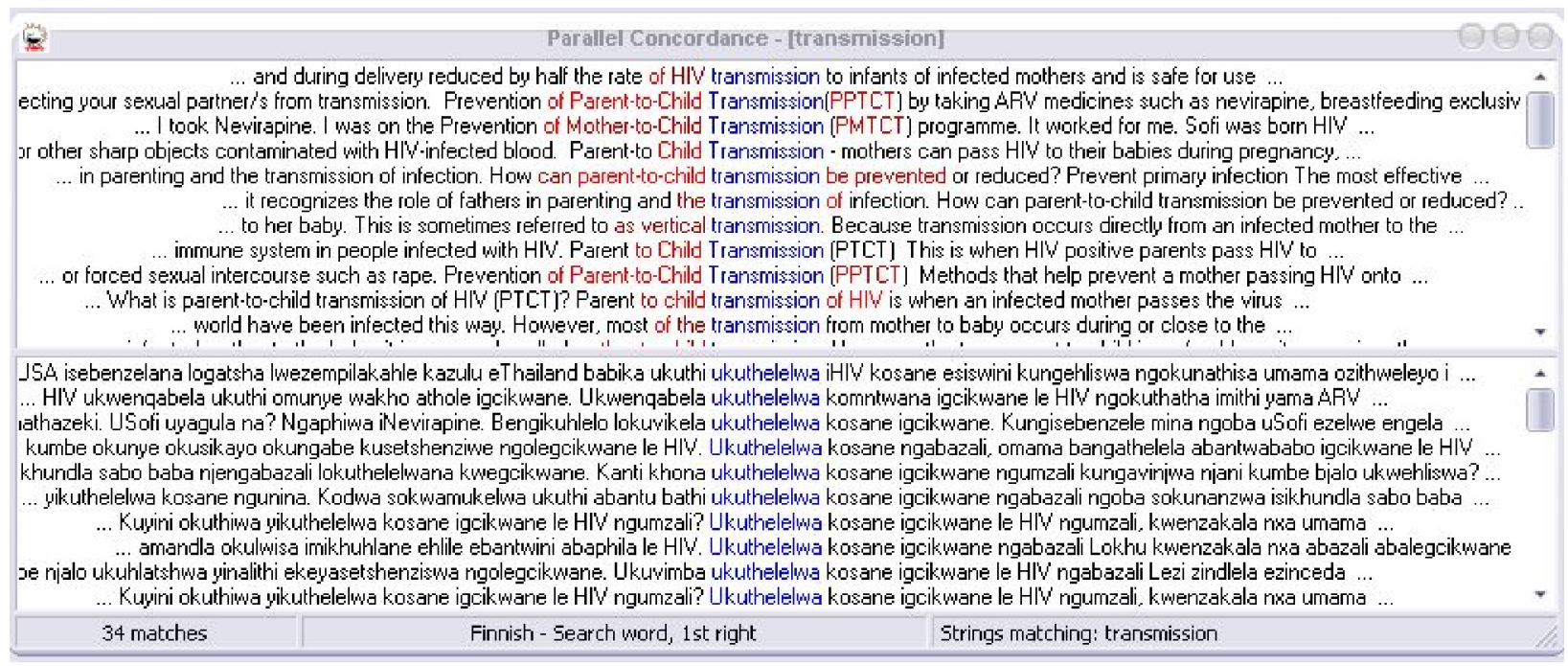

Figure 3. Translation of the term "transmission"

Ndebele translators are in agreement about the translation of "transmission", and this is important for its standardisation. The strategy of extending meanings of old words therefore reflects that Ndebele is a dynamic language that is growing through its interaction with other languages. However, Batibo (in Van Huyssteen 1999:183) warns that the transparency of 
meaning may disappear in the extended meaning. The following section is an analysis of paraphrasing as a term-creation strategy.

\subsubsection{Paraphrasing}

Paraphrasing involves explaining the source concept in the target text, as shown in the examples in Table 9 below.

Table 9. Paraphrasing

\begin{tabular}{|c|l|c|c|}
\hline \multicolumn{1}{|c|}{ Source term } & \multicolumn{1}{|c|}{ Target term } & $\begin{array}{c}\text { ENG word } \\
\text { count }\end{array}$ & $\begin{array}{c}\text { ND word } \\
\text { count }\end{array}$ \\
\hline 1. defence system & Amabutho omzimba & 2 & 2 \\
\hline 2. immune system & $\begin{array}{l}\text { Amandla okulwisa imikhuhlane/ } \\
\text { amasotsha omzimba }\end{array}$ & 44 & 8 \\
\hline $\begin{array}{l}\text { 3. exclusive } \\
\text { breastfeeding }\end{array}$ & $\begin{array}{l}\text { ukumunyisa uchago lukamama } \\
\text { lodwa }\end{array}$ & 3 & 2 \\
\hline 4. sexual partner/s & Izithandwa zamacansi & 5 & 3 \\
\hline \multicolumn{2}{|l|}{ Overall word count: 295} & & $\begin{array}{c}\text { Frequency: } \\
0.8008\end{array}$ \\
\hline
\end{tabular}

Paraphrasing is the third most popular strategy, after pure loaning and semantic shift. In Table 9, there is a huge difference between the word count for the search word "immune system" and the target translations which are amandla okulwisa imikhuhlane (8) and amasotsha omzimba (7). The discrepancy is a result of agreement concords that change the phrasing of the terms, for example:

(v) ST: Immune deficiency means a weakness in the body's immune system.

TT: Immune deficiency itsho ukwehla kwamandla amasotha alwisana lemikhuhlane emzimbeni.

BT: Immune deficiency means reduction of the body's ability to fight illnesses.

Through this strategy, the Ndebele language has seen the introduction and growth of terms and phrases that capture new concepts in indigenous ways. The next strategy under discussion is coinage.

\subsubsection{Coinage}

Coinage involves developing new terms by using internal resources to capture new meanings in a language. The examples in Table 10 show that Ndebele is responding to changes in the medical world by coining new words to explain new concepts. 
Table 10. Coinage

\begin{tabular}{|l|l|c|c|}
\hline \multicolumn{1}{|c|}{ Source term } & \multicolumn{1}{|c|}{ Target term } & ENG word count & ND word count \\
\hline 1. candida & umkhuhlane wemvubela & 2 & 2 \\
\hline 2. abstinence & ukuzila amacansi & 8 & 5 \\
\hline 3. ribbon & umcikiliso & 2 & 2 \\
\hline 4. homosexual & izitabane & 1 & 1 \\
\hline 5. diabetes & itshukela & 2 & 2 \\
\hline \multicolumn{2}{|c|}{ Overall word count: 20} & & Frequency: 0.0542 \\
\hline
\end{tabular}

Overall, 20 words were identified as coinages, with some appearing more than once in the Ndebele corpus. Compared to borrowing, which comes in various forms such as indigenisation, pure loaning of words, acronyms and abbreviations and pure loaning preceded by explanations, the strategy of coinage is one of the least used in the ENPC. Nevertheless, some of the coined words such as itshukela for "diabetes" and izitabane for "homosexuality" have gained prominence in the Ndebele community. Another strategy that is used by Ndebele translators to create terms is compounding, as briefly elaborated in the next section.

\subsubsection{Compounding}

Cluver (1989) describes compounding as a process which involves combining two or more words (two nouns, a noun and a verb, etc.) into one unit. That is, compounding is a method of term development that involves creating terms using other words or parts of speech. In the ENPC, Ndhlovu (2012:203) found one example of compounded terms:

$$
\text { drugs }>\text { izidakamizwa }(i z i+d a k a=\text { to intoxicate })+m i z w a \text { (senses })
$$

Compounding is the least used strategy in the ENPC, though it has great potential to introduce new words by combining already existing words.

\section{Summary of findings}

To summarise, the strategies presented in section 4 had the following word counts and frequencies:

Table 11. Strategies used in the ENPC

\begin{tabular}{|c|c|c|}
\hline Strategy & Word count & Frequency \% \\
\hline 1. Indigenisation & 146 & 0.3963 \\
\hline 2. Pure loan words & 196 & 0.5320 \\
\hline $\begin{array}{l}\text { 3. Acronyms and } \\
\text { abbreviations }\end{array}$ & 849 & 2.3047 \\
\hline $\begin{array}{l}\text { 4. Abbreviations preceded } \\
\text { by an explanation }\end{array}$ & 20 & 0.0542 \\
\hline $\begin{array}{l}\text { 5. Paraphrased acronyms } \\
\text { and abbreviations }\end{array}$ & 31 & 0.0841 \\
\hline $\begin{array}{l}\text { 6. Pure loan words } \\
\text { preceded by an } \\
\text { explanation }\end{array}$ & 48 & 0.1303 \\
\hline
\end{tabular}




\begin{tabular}{|c|c|c|}
\hline $\begin{array}{l}\text { 7. Using borrowed } \\
\text { synonyms }\end{array}$ & 271 & 0.7356 \\
\hline 8. $\quad$ Semantic shift & 422 & 1.1455 \\
\hline 9. $\quad$ Paraphrasing & 295 & 0.8008 \\
\hline 10. Coinage & 20 & 0.0542 \\
\hline 11. Compounding & 1 & 0.0027 \\
\hline
\end{tabular}

The main finding of this research is that borrowing in the form of pure loaning of acronyms and abbreviations; pure loan words; indigenisation; pure loan words preceded by explanations and acronyms; and abbreviations preceded by an explanation are the most common strategies in the ENPC. Under borrowing, pure loaning of acronyms and abbreviations, followed by pure loaning of words, were used to a larger extent. Borrowing was followed by semantic shift, paraphrasing and using borrowed synonyms. The least used strategies were paraphrasing acronyms and abbreviations, coinage and compounding (in this order).

Secondly, a true reflection of strategies used by Ndebele translators in the ENPC requires one to have an intimate knowledge of the prefixal elements of all terms, as identifying head words and concords outside their agreement created an incomplete picture of the strategies used.

Thirdly, due to the lack of terminology, there is an overlap of terms and meaning in the Ndebele language, where a number of source terms are translated using one word in Ndebele. For example, the terms "pills", "medicines", "pain killers" and "dose" are translated as amaphilisi. This means that there is clearly a need to develop adequate technical terminology to translate health texts in the Ndebele language.

Lastly, ParaConc as a tool for analysis provided relevant data in terms of word counts, alphabetical lists, frequencies and words in context that contributed to understanding the strategies used by Ndebele translators in the health sector.

\section{Conclusion}

This article explored strategies used by Ndebele translators in the Zimbabwe health sector to create terms. This was done by investigating an English-Ndebele Parallel Corpus (Ndhlovu 2012) by means of a parallel concordance, ParaConc. Through ParaConc, the researcher was able to identify source terms and their equivalent translations in the Ndebele language, draw frequencies, word counts, alphabetical lists, other possible translations and "hot words". It was noted that pure borrowing is the most commonly used strategy, and this was supported by word counts and frequency of terms in the Ndebele corpus. Borrowing involves various strategies such as the use of pure loan words, pure loan words preceded by an explanation, acronyms and abbreviations, paraphrased acronyms and abbreviations, and indigenised loan words. It was found that the lesser the frequency of a term, the higher the chances of the term being retained in its pure form. With regard to acronyms and abbreviations, most were retained in their pure forms but some were paraphrased. The reason why most translators rely on pure loan words could be that this is an easy option as most translators have not received any formal training (Ndhlovu 2012). Furthermore, in Zimbabwe, English as the only official language is also the dominant language, and it seems as if translators assume that their readers will understand borrowed terms even though the structure of these terms is alien to the Ndebele language. The Zimbabwean situation is contrary to the South African linguistic 
environment, where the Constitution stipulates that all 11 languages are equal and where all 11 languages are in fact minority languages (Kruger 2010). This finding points to a dire need to train translators in Zimbabwe and also that a language policy should be developed that takes cognisance of all of the languages spoken in Zimbabwe. The least used strategies are paraphrasing acronyms and abbreviations, coinage and compounding (in that order). There is a need for terminographers to continue developing terms, working hand-in-hand with other language experts and researchers in order to fill the gap of terminology scarcity in African languages.

\section{References}

Baker, M. 1992. In other words: A coursebook on translation. London: Routledge.

Baker, M. 2011. In other words: A coursebook on translation. London: Routledge.

Cluver, A.D. de V. 1989. A manual of terminography. Pretoria. Human Sciences Research Council.

Dictionary Unit for South African English. 2007. South African concise Oxford dictionary. Cape Town: Oxford University Press.

Gauton, R., E. Taljard and G.-M. De Schryver 2003. Towards strategies for translating terminology into all South African languages: A corpus-based approach. In G.-M. De Schryver (ed.) TAMA 2003, South Africa. Terminology in advanced management applications. $6^{\text {th }}$ international TAMA conference: Conference proceedings. Pretoria: (SF) 2 Press. pp. 81-88.

Hadebe, S. 2000. Developing terminology in African languages with special reference to Ndebele. In E.M. Chiwome, Z. Mguni, M. Furusa and W.A. Little (eds.) Indigenous knowledge and technology in African and diasporan communities: Multi-disciplinary approaches. Harare: South African Association for Culture and Development Studies. pp. 228-232.

Hadebe, S. 2001. IsiChazamazwi SesiNdebele. Harare: College Press and African Languages Research Institute.

Hadebe, S. 2006. The standardisation of the Ndebele language through dictionary-making. Harare: ALLEX Project.

Kruger, A. and K. Wallmach. 1999. 'Putting a sock on it': A contrastive analysis of problemsolving translation strategies between African and European languages. South African Journal of African Languages 19(4): 275-289.

Kruger, A. 2010. Translating public information texts on health issues into languages of limited diffusion in South Africa. In R.A. Valdeón (ed.) Translating information. Oviedo: University of Oviedo Press (Eduino). pp. 150-166. 
Moropa, K. 2005. An investigation of translation universals in a parallel corpus of EnglishXhosa texts. Unpublished D.Litt et Phil. thesis. Pretoria: University of South Africa.

Mtintsilana, P.N. and R. Morris. 1988. Terminology in African languages in South Africa. South African Journal of African Languages 8(4): 109-113.

Ndhlovu, K. 2012. An investigation of strategies used by Ndebele translators in Zimbabwe in translating HIV/AIDS texts: A corpus based approach. Unpublished $\mathrm{PhD}$ thesis. Alice: University of Fort Hare.

Nkomo, D. and N. Moyo. 2006. IsiChazamazwi SezoMculo. Gweru. Mambo Press.

Pelling, J.N. 1971. A practical Ndebele dictionary. Bulawayo. Longman Rhodesia.

Trew. R. 1994. The development of training models for African language translators and interpreters. In A. Kruger (ed.) 2004. New perspectives on teaching translators and interpreters in South Africa. Pretoria: University of South Africa. pp. 73-102.

Valeontis, K. and E. Mantzari. 2006. The linguistic dimension of terminology: Principles and methods of term formation. $1^{\text {st }}$ Athens International Conference on Translation and Interpretation: Between Art and Social Science. 13-14 October 2006, Athens, Greece. pp. 120 .

Van Huyssteen, L. 1999. Problems regarding term creation in Southern African languages, with special reference to Zulu. South African Journal of African Languages 19(3): 179-187. 